\title{
PELATIHAN DAN PENDAMPINGAN UNTUK MENINGKATKAN PENGETAHUAN DAN MINAT DALAM MENULIS KARYA ILMIAH MAHASISWA PROGRAM STUDI ADMINISTRASI PUBLIK STIA MUHAMMADIYAH SELONG
}

\author{
Ratna Yuniarti ${ }^{1}$, Sandy Ari Wijaya ${ }^{2}$, Salmi Yuniar Bahri ${ }^{3}$, Muhammad Atha Iqbal ${ }^{4}$ \\ 1,2,3,4 STIA Muhammadiyah Selong, Kota Selong, NTB \\ E-mail : ratna.matika@gmail.com
}

\begin{abstract}
ABSTRAK
Tujuan kegiatan pengabdian ini adalah memberikan pelatihan dan pendampingan kepada mahasiswa untuk meningkatkan pengetahuan dan minat dalam menulis karya ilmiah skripsi. Kegiatan ini dilaksanakan secara tatap muka terbagi menjadi empat sesi kegiatan. Pada kegiatan pelatihan disampaikan materi yang berkaitan tentang metodologi penelitian. Metode digunakan bervariasi dengan ceramah, diskusi, demonstrasi, dan latihan. Materi yang disampaikan pada kegiatan ini adalah: 1) Metode penelitian dan sistematika penyusunan proposal penelitian, 2) Pemilihan pendekatan penelitian (kualitatif atau kuantitatif), 3)Teknik pengumpulan data, 4) Instrument, 5) Teknik analisis data. Target materi tidak dapat disampaikan secara detail karena keterbatasan waktu. Untuk memaksimalkan kegiatan ini dilanjutkan dengan memberikan pendampingan bagi peserta yang sedang menyelesaikan tugas akhir. Pendampingan ini diberikan untuk mempercepat proses penyelesaian tugas akhir mahasiswa terutama yang tak kunjung selesai. Secara garis besar kegiatan ini dapat berjalan sesuai dengan target. Program pelatihan dapat diselenggarakan dengan baik dan berjalan dengan sesuai dengan rencana kegiatan yang telah disusun. Selama kegiatan ini rasa percaya diri dan minat mahasiswa semakin meningkat dilihat dari antusias dan keaktifan dalam diskusi Tanya jawab.
\end{abstract}

Kata kunci:Pelatihan, Pendampingan, Pengetahuan, Minat, Karya Ilmiah

\begin{abstract}
The purpose of this activity is to provide training and assistance to students to increase their knowledge and interest in writing scientific thesis. This activity is carried out face-to-face and is divided into four activity sessions.During the training activities, materials related to research methodology were delivered.The methods used vary with lectures, discussions, demonstrations, and exercises. The materials presented in this activity are:1) Research methods and systematics for preparing research proposals, 2)Selection of research approach (qualitative or quantitative), 3)Data collection techniques, 4) Instruments, 5) Data analysis techniques. The target material cannot be delivered in detail due to time constraints. To maximize this activity, it is continued by providing assistance for participants who are completing their final project. This assistance is given to speed up the process of completing student final assignments, especially those that have not been completed.In general, this activity can run according to the target. The training program can be well organized and run according to the activity plans that have been prepared. During this
\end{abstract}


activity, students' self-confidence and interest increased, as seen from their enthusiasm and activeness in discussions.

Keywords: Training, Mentoring, Knowledge, Interests, Scientific Work

\section{PENDAHULUAN}

Pada dasarnya seluruh perguruan tinggi di Indonesia mewajibkan setiap mahasiswa membuat karya ilmiah sebagai syarat kelulusan. Jenis karya ilmiah seperti jurnal ilmiah, laporan penelitian, disertasi, tesis, skripsi, dan makalah. Skripsi misalnya, bermaksud untuk menguji kualitas dan kompetensi mahasiswa dalam menjawab persoalan yang ada di kehidupan masyarakat. Bagi sebagian mahasiswa skripsi menjadi sebuah momok yang menakutkan. Kewajiban itu sering dianggap sebagai tugas berat oleh mahasiswa karena kurangnya kemampuan dan kebiasaan dalam menyusun karya ilmiah itu sendiri (Saman dan Bakhtiar, 2018).Untuk menghasilkan skripsi yang berkualitas dibutuhkan pengetahuan tentang metodologi penelitian dan keterampilan menulis. Pengetahuan tentang metodologi penelitian misalnya dalam pemilihan metode penelitian dan menentukan teknik analisis data yang tepat. Sedangkan keterampilan menulis adalah keterampilan dalam berkomunikasi secara tulisan.

Pengetahuan tentang metode penelitian sudah didapatkan mahasiswa pada beberapa mata kuliah yang telah ditempuh selama perkuliahan. Namun, akan cepat menguap jika tidak dipraktekkan. Menulis ilmiah merupakan salah satu cara praktek untuk melatih ilmu yang telah dipelajari. Keterampilan menulis akan semakin baik jika selalu produktif menghasilkan tulisan. Menulis ilmiah merupakan aktivitas yang sangat berhubungan dengan dunia pendidikan dan penelitian. Menulis merupakan kemampuan yang perlu diasah dan dilatih. Rendahnya motivasi mahasiswa untuk menjadikan menulis sebagai kebiasaan adalah salah satu faktor penyebab mahasiswa tersebut tak kunjung lulus. Program Studi Administrasi Publik STIA Muhammadiyah Selong mewajibkan mahasiswa menulis karya ilmiah berupa skripsi sebagai salah satu syarat mendapatkan gelar sarjan. Pengalaman pemateri sebagai dosen sekaligus pembimbing skripsi di Program Studi Administrasi Publik menemukan bahwa lamanya mahasiswa menyelesaikan proposal skripsi dari sejak disetujuinya skripsi paling sedikit 3 bulan. Masih ada ditemukan mahasiswa yang menyelesaikan skripsi lebih dari satu tahun. Berdasarkan wawancara dengan beberapa mahasiswa beberapa permasalahan yang menyebabkan lamanya waktu menyelesaikan skripsi adalah kurangnya pemahaman tentang metodologi penelitian, kurangnya keterampilan menulis, serta kurangnya wawasan tentang topic penelitian yang diajukan. Beberapa permasalahan yang ditemukan ini berakibat kurangnya minat mahasiswa menyelesaikan tugas akhirnya.

Permasalahan yang dihadapi mahasiswa ini tentu saja harus menemukan penyelesaiannya. Lamanya mahasiswa menyelesaikan tugas akhir berakibat lamanya masa studi mahasiswa. Masa studi lebih dari empat tahun tentu saja berakibat pada kualitas lulusan yang dihasilkan suatu perguruan tinggi. Oleh sebab itu, pemateri menawarkan solusi dalam permasalahan ini. Pertama, untuk meningkatkan pengetahuan mahasiswa tentang metodologi penenelitian dengan memberikan workshop materi metodologi penelitian. Mulai dari cara menyusun judul sampai analisis data. Kedua, 
memberikan pendampingan secara berkelanjutan. Pendampingan ini bertujuan untuk memantau terus perkembangan tugas akhir mahasiswa. Ketiga, membuka forum diskusi secara rutin. Untuk memperluas wawasan mahasiswa tentang topic yang diangkat, diperlukan diskusi antar mahasiswa yang didampingi oleh narasumber.

Beberapa pengabdian masyarakat yang telah dilakukan antara lain "Pelatihan Penulisan Artikel Ilmiah bagi Mahasiswa Pendidikan BiologiFPMIPA IKIP Mataram" oleh Septina dkk (2020) menunjukkan hasil yang sangat memuaskan. Dikatakan bahwa pelatihan tersebut dapat meningkatkan kemampuan mahasiswa dalam menulis artikel ilmiah. Selain itu, kegiatan yang sama dilakukan oleh Suprihati(2021) "Pelatihan Penulisan Karya Ilmiah (Tugas Akhir dan Skripsi) Bagi Mahasiswa D3 dan S1" menunjukkan antusias yang luar biasa. Hal ini ditinjau dari banyaknya pertanyaan yang diberikan peserta. Hal senada juga dikatakan M. Hasan Ma'ruf (2021), bahwa setelah melakukan kegiatan "Pelatihan Penulisan Artikel Ilmiah dari Skripsi dan Tesis UntukMahasiswa Serta Cara Publikasinya ke Jurnal Nasional" dapat menumbuhkan semangat pada peserta, adanya respon positif terhadap pelaksanaan pelatihan dan banyak peserta yang antusias bertanya.

Kegiatan pengabdian ini bertujuan untuk meningkatkan pengetahuan dan minat dalam menulis karya ilmiah mahasiswa program studi administrasi public STIA Muhammadiyah Selong. Sehingga menulis skripsi itu tidak lagi menjadi momok yang menakutkan.Kegiatan ini tidak hanya dengan memberikan pelatihan, tetapi juga pendampingan yang berkelanjutan. Untuk memaksimalkan kegiatan ini peserta diberikan tugas menyusun proposal penelitian. Sehingga target kegiatan ini untuk mendampingi mahasiswa peserta agar dapat menyelesaikan tugas akhir tepat waktu.

\section{METODE}

Permasalahan yang ditemukan di Program Studi Administrasi Publik adalah lamanya mahasiswa dalam menyelesaikan skripsi. Maka untuk mengatasinya adalah Pertama, meningkatkan pengetahuan mahasiswa tentang metodologi penenelitian dengan memberikan workshop materi metodologi penelitia. Kedua, memberikan pendampingan secara berkelanjutan. Pendampingan ini bertujuan untuk memantau terus perkembangan tugas akhir mahasiswa. Ketiga, membuka forum diskusi secara rutin

Kegiatan workshop dilakukan secara offline (tatap muka) di Gedung Aula STIA Muhammadiyah Selong. Metode Penyampaian yang bervariasi digunakan agar peserta tidak merasa bosan dan penjelasan pemateri mudah dipahami.Beberapa metode yang digunakan adalah:

1. Ceramah . 
Untuk meningkatkan pengetahuan mahasiswa tentang metodologi penenelitian dengan memberikan workshop materi metodologi penelitian.Penyampaian materi dilakukan melalui ceramah. Pemateri menampilkan Power Point sebgai media sehingga ceramah lebih hidup dan tidak monoton. PPT dengan animasi membuat konsep-konsep penting penelitian yang disampaikan menjadi lebih menarik dan mudah diterima. Materi yang diberikan meliputi: penyusunan proposal mulai dari penyusunan rumusan masalah, pemilihan pendekatan penelitian (kualitatif atau kuantitatif), pemilihan sampel, dan penyusunan instrument. Agar kegiatan tidak monoton kegiatan ini diselingi tanya jawab antara pemateri dan peserta.

\section{Demonstrasi}

Selain ceramah pemateri juga menggunakan metode demonstrasi. Dimana pemateri memberikan contoh bagaimana menyusun judul berdasarkan masalah yang ditemukan.Pemateri mendemonstrasikan kepada peserta dengan memberikan contoh masalah dalam kehidupan sehari-hari kemudian menyusunnya menjadi sebuah judul penelitian. Kegiatan demonstrasi ini untuk membuka wawasan mahasiswa yang selama ini tidak tersalurkan. Pada kegiatan ini minat mahasiswa mulai meningkat, ditunjukkan dengan beberapa contoh permasalahan yang ditemukan mahasiswa. Beberapa mahasiswa meminta pemateri menanggapi permasalah tersebut sampai bisa diangkat menjadi sebuah judul.

\section{Latihan}

Agar kegiatan ini berkelanjutan maka pemateri memberikan latihan kepada peserta untuk menyusun sebuah judul dan menyusun proposalnya. Latihan dikumpulkan setelah pelatihan dan proses penyususnannya melalui pendampingan oleh para tutor. Dengan ini peserta akan langsung terlibat dan mempraktekkan ilmu yang didapatkan selama pelatihan. Pemateri membuka forum diskusi secara rutin. Untuk memperluas wawasan mahasiswa tentang topic yang diangkat. Agar ilmu yang didapatkan selama pelatihan tidak menguap diperlukan diskusi secara rutin antar mahasiswa yang didampingi oleh narasumber.

Setelah diberikan workshop, maka langkah selanjutnya adalah memberikan pendampingan kepada peserta untuk menyelesaikan tugas akhir. Kegiatan ini dilakukan supaya kemajuan peserta dapat dikontrol. Metode terakhir dalam kegiatan ini adalah mengadakan diskusi secara rutin antar mahasiswa. Dimana dalam forum ini mahasiswa saling bertukar pengalaman selama menyelesaikan skripsinya. Sehingga permasalahan yang dihadapi dalam proses penyusunan mendapat solusi penyelesaian.

\section{HASIL DAN PEMBAHASAN}

Tahap awal kegiatan pengabdian ini adalah melakukan sosialisasi melalui media kampus tentang kegiatan workshop yang akan dilaksanakan. Kemudian para peserta melakukan pendaftaran secara online pada panitia penyelenggara. 
Workshop dilaksanakan dengan cara tatap muka berjalan dengan baik dan lancar. Metode dikombinasikan antara ceramah dan demonstrasi, dilanjutkan latihan/praktek untuk membuat proposal, mulai dari observasi lapangan, identifikasi masalah, pemilihan pendekatan penelitian dan penyusunan instrument. Kegiatan ini dilaksanakan sehari yaitu pada April-Oktober 2021. Kegiatan Pelatihan dilaksanakan pada hari sabtu tanggal 10 April 2021 dari pukul 08.00-18.00 WITA. Kemudian setelah pelatihan diberikan pendampingan bagi mahasiswa dalam menyusun proposal skripsi, dan menyusun laporan akhir skripsinya. Peserta kegiatan berjumlah 38 orang mahasiswa program studi Administrasi Publik STIA Muhammadiyah Selong. Peserta kegiatan ini sebagian besar berasal dari mahasiswa semester akhir yang akan menyusun skripsi. Sehingga kami berinisiatif memberikan pendampingan sampai bulan Oktober bagi mahasiswa yang sedang menyusun skripsi. mengenai:

Pelaksanan kegiatan pelatihan ini dengan pokok bahasan yang disampaikan

1. Metode penelitian dan sistematika penyusunan proposal penelitian

2. Pemilihan pendekatan penelitian (kualitatif atau kuantitatif)

3. Pemilihan sampel, dan penyusunan instrument

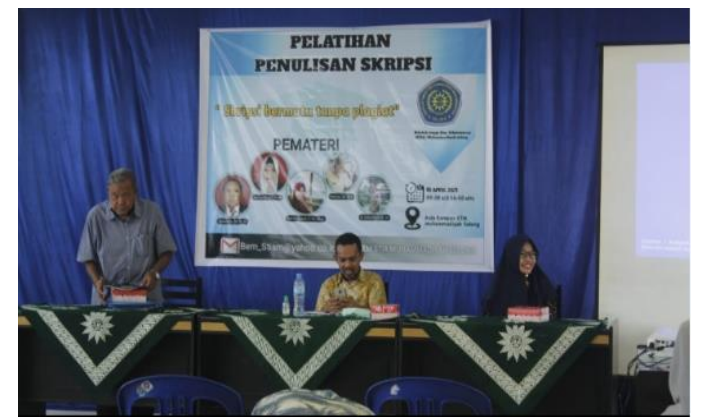

Gambar 1. Penyampaian Materi

Kegiatan ini dilaksanakan selama empat sesi. Pada sesi pertama, materi yang disampaikan tentang bagaimana menentukan topik permasalahan yang dapat dijadikan judul penelitian. Menyusun judul yang baik sesuai dengan bidang keilmuan. Pada sesi kedua, materi yang disampaikan tentang penelitian dengan pendekatan kualitatif dan kuantitatif. Disesi ini peserta terlibat sangat aktif. Pertanyaan yang diajukan pun mulai dari hal yang mendasar. Minat mahasiswa untuk lebih memahami kedua jenis pendekatan ini semakin meningkat ketika pemateri menunjukkan perbedaan contoh penyusunan proposal dengan pendekatan kualitatif dan kuantitatif. Materi pada sesi ketiga, teknik pengumpulan data. Pada sesi ini pemateri menyampaikan teknik pengumpulan data berupa dokumentasi, kuestioner/angket, wawancara, observasi, dan tes. Kemudian peserta diberikan contoh cara menyusun instrument. Dimulai dari membuat kisi-kisi sampai perumusan item berdaarkan indicator yng telah disusun. Pada sesi keempat, materi terahir yang disampaikan adalah teknik analisis data. Pada sesi ini disampaikan secara singkat tentang software statistic yang dapat membantu dalam menyelasaikan analisis data. 
Semua yang tidak dapat disampaikan secara detail karena waktu yang terbatas. Disesi terakhir Tanya jawab antusias peserta semakin meningkat karena banyaknya pertanyaan. Sehingga moderator membatasi jumlah pertanyaan. Berbagai pertanyaan diungkapkan peserta dengan antusias. Secara garis besar pertanyaan yang diajukan para peserta adalah:

1. Bagaimana memilih pendekatan statistik yang tepat dalam penelitian

2. Bagaimana menyusun latar belakang

3. Bagaimana melakukan analisis data

4. Bagaimana cara memilih sampel

5. Bagaiman cara membuat angket

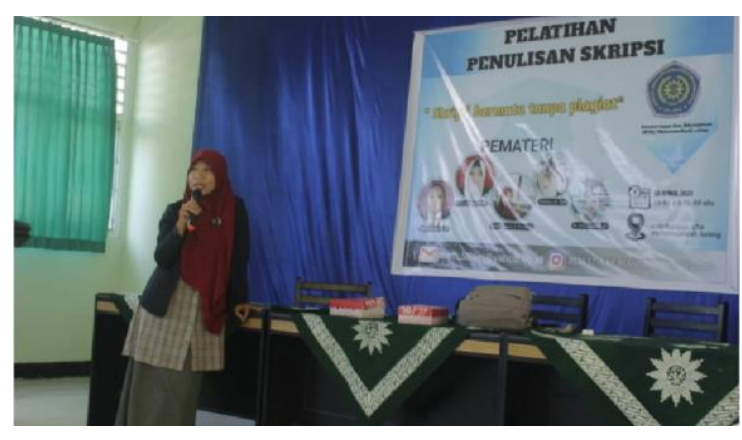

\section{Gambar 2. Kegiatan Diskusi tanya Jawab}

Program pengabdian pada masyarakat berupa pelatihan dan pendampingan penyusun proposal dan hasil penelitian merupakan kegiatan pelatihan offline pertama yang dilakukan selama masa pandemic. Kegiatan ini dilaksanakan dengan mematuhi protocol kesehatan. Setelah diadakan program pengabdian ini diharapkan dapat menambah pengetahuan tentang metode penelitian, dan keterampilan menulis serta dapat meningkatkan semangat, motivasi dan rasa percaya diri dalam melakukan penelitian. Selain itu, mahasiswa akan lebih termotivasi menyelesaikan tugas akhir/skripsi. Hasil kegiatan pengabdian ini diharapkan juga akan bermanfaat bagi institusi antara lain mahasiswa menghasilkan penelitian yang berkualitas dan masa studi mahasiswa lebih cepat. Beberapa Komponen hasil kegiatan secara garis besar mencakup sebagai berikut:

1. Tercapai target peserta pelatihan

2. Tercapai tujuan pelatihan

3. Tercapai target materi yang telah direncanakan

4. Tercapai kemampuan peserta dalam penguasaan materi

Target peserta pelatihan ini mahasiswa semester akhir yang akan dan sedang menyelesaikan tugas akhir. Dalam pelaksanaannya, kegiatan ini diikuti oleh 38 orang peserta berasal dari mahasiswa tingkat akhir. Target tujuan pelatihan ini secara garis besar sudah tercapai, namun keterbatasan waktu yang disediakan mengakibatkan tidak semua materi disampaikan secara detil. Ketercapaian target materi pada kegiatan ini cukup 
baik, karena keseluruhan materi telah dapat disampaikan secara garis meskipun tidak sedetil yang telah direncanakan. Garis besar materi yang telah disampaikan adalah:

1. Metode penelitian dan sistematika penyusunan proposal penelitian

2. Pemilihanpendekatan penelitian (kualitatif atau kuantitatif)

3. Teknik pengumpulan data

4. Instrument

5. Teknik analisis data

Kemampuan mahasiswa dalam latihan menyusun rumusan masalah dan menyusun latar belakang masih kurang dikarenakan waktu yang singkat dalam penyampaian materi dan kemampuan para peserta yang berbeda-beda. Hal ini disebabkan jumlah materi yang banyak hanya disampaikan dalam waktu sehari sehingga tidak cukup waktu bagi para peserta untuk memahami dan mempraktekkan secara lengkap semua materi yang diberikan. Secara keseluruhan kegiatan pelatihan pengolahan dan analisis data dapat dikatakan berhasil. Keberhasilan ini dilihat dari manfaat yang diperoleh peserta adalah dapat memahami metode penelitian dan motivasi mahasiswa sudah mulai tumbuh terlihat dari pertanyaan yang diajukan dan hasil latihan yang diberikan. Untuk memaksimalkan kegiatan ini, kami memberikan pendampingan kepada mahasiswa yang sedang menyelesaikan tugas akhir. Terutama bagi mahasiswa yang tak kunjung lulus. Kegiatan pendampingan secara intensip ini dilakukan dengan memberikan target. Sehingga kami menargetkan mahasiswa angkatan lama ini dapat lulus di tahun ini.

Berdasarkan hasil observasi setelah diadakan workshop dan pendampingan, mahasiswa peserta menunjukkan hasil yang signifikan dalam menyelesaikan skripsinya. Lamanya mahasiswa menyelesaikan proposal penelitiannya ditunjukkan pada table dibawah ini:

Tabel 1. Data Lamanya Waktu Menyelesaikan Proposal Penelitian

\begin{tabular}{|cc|}
$\begin{array}{c}\text { Lamanya waktu } \\
\text { menyelesaikan proposal } \\
\text { penelitian }\end{array}$ & $\begin{array}{c}\text { Jumlah } \\
\text { mahasiswa } \\
\text { peserta }(\text { orang) }\end{array}$ \\
\hline $\mathbf{1}<\mathbf{x} \leq \mathbf{3}$ bulan & 20 \\
$\mathbf{3}<\mathbf{x} \leq \mathbf{5}$ bulan & 17 \\
$\mathbf{5}<\mathbf{x} \leq 7$ bulan & 1 \\
$\mathbf{7}<\mathbf{x} \leq \mathbf{9}$ bulan & - \\
$\mathbf{9}<\mathbf{x} \leq \mathbf{1 1}$ bulan & - \\
$>\mathbf{1 1}$ bulan & - \\
\hline
\end{tabular}

Semua mahasiswa yang mengikuti pelatihan dan pendampingan kegiatan pengabdian ini dapat menyelesaikan skripsi sesuai dengan target. Pada ujian proposal gelombang 1 pada tanggal 25 Juni 2021, 20 orang mahasiswa megikuti ujian proposal. 
Kemudian pada tangga 3 Juli 2021, 17 mahasiswa mengikuti ujian proposal tahap 4. Dan pada tanggal 10 juli 2021, 1 orang mahasiswa peserta pelatihan mengikuti ujian proposal gelombang 5. Dari 38 peserta pelatihan dan pendampingan semua dapat menyelesaikan proposal dan skripsi tepat sesuai target yang ditentukan. Semua peserta pelatihan dapat mengikuti ujian skripsi hasil penelitian yang dilaksanakan bulan Oktober 2021.

\section{KESIMPULAN}

Program pelatihan dapat diselenggarakan dengan baik dan berjalan dengan sesuai dengan rencana kegiatan yang telah disusun. Kegiatan ini mendapat sambutan sangat baik terbukti dengan keaktifan peserta mengikuti pelatihan dan pendampingan. Peserta tidak meninggalkan tempat sebelum waktu pelatihan berakhir. Hal ini menunjukkan kegiatan pelatihan dan pendampingan ini terbukti dapat meningkatkan pengetahuan dan minat mahasiswa dalam menulis karya ilmiah. Oleh karena itu, kami sangat mengharapkan pelatihan ini dapat dilanjutkan pada program pengabdian selanjutnya. Kegiatan sangat baik karena target kelulusan lebih cepat. Berdasarkan evaluasi yang telah dilakukan dapat diajukan beberapa saran sebagai berikut:

1. Waktu pelaksanaan kegiatan pengabdian perlu ditambah agar tujuan kegiatan dapat tercapai sepenuhnya.

2. Adanya kegiatan lanjutan yang berupa pelatihan sejenis selalu diselenggarakan secara periodik sehinga dapat meningkatkan kempuan mahasiswa.

\section{Ucapan Terima Kasih}

Ucapan terimakasih ditujukan kepada BEM STIA Muhammadiyah Selong Selaku Panitia pelaksana kegiatan ini sehingga acara dapat berjalan dengan lancar

\section{REFERENSI}

Abdul Saman, M. Ilham Bakhtiar, Karya Tulis Ilmiah Bagi Mahasiswa STKIP Andi Matappa Kabupaten Pangkep. Jurnal Terapan Abdimas, Volume 3, Nomor 1, Januari 2018, hlm. 39-43. (artikel web). Diakses dari:

http://e-journal.unipma.ac.id/index.php/JTA/article/view/2165/1541

M. Hasan Ma'ruf,\&Tira Nur Fitria, Pelatihan Penulisan Artikel Ilmiah dari Skripsi dan Tesis Untuk Mahasiswa Serta Cara Publikasinya ke Jurnal Nasional. Jurnal ABDAYA : Pengabdian dan Pemberdayaan Masyarakat Vol. 1, No. 1, 2021, Hal. 6-13 (Artikel web) diakses dari: https://www.researchgate.net/publication/355473502 Pelatihan Penulisan_Artik el_Ilmiah_dari_Skripsi_dan_Tesis_Untuk_Mahasiswa_Serta_Cara_Publikasinya _ke_Jurnal_Nasional 
Septiana Dwi Utami, dkk. Pelatihan Penulisan Artikel Ilmiah bagi Mahasiswa Pendidikan BiologiFPMIPA IKIP Mataram. Mei 2020. Vol. 1, No. 1 hal 28-33. (Artikel web). Diakses dari:

https://e-journal.undikma.ac.id/index.php/jpu/article/view/2572

Suprihati, \& Tira Nur Fitria, Pelatihan Penulisan Karya Ilmiah (Tugas Akhir dan Skripsi) Bagi Mahasiswa D3 dan S1 Di Provinsi Jawa dan Luar Jawa . Jurnal Pengabdian Masyarakat :TRISNAMAS. : Vol. 1, No. 1, 2021 hal 1-9. (artikel web). Diakses darihttps://www.researchgate.net/publication/355473585_PELATIHAN_PENUL ISAN_KARYA_ILMIAH_TUGAS_AKHIR_DAN_SKRIPSI_BAGI_MAHASI SWA_D3_DAN_S1_DI_PROVINSI_JAWA_DAN_LUAR_JAWA 